\section{Single-parenting: a case of class division on ideas of marriage and motherhood}

\author{
Maria Carolina Tomás*
}

\begin{abstract}
EDIN, Kathryn; KEFALAS, Maria. Promises I can keep: why poor women put motherhood before marriage, with a new preface. 3rd edition. Berkeley, Los Angeles, London: University of California Press, 2011, $308 \mathrm{p}$.
\end{abstract}

To most middle-class observers, depending on their philosophical take on things, a poor woman with children but no husband, diploma, or job is either a victim of her circumstances or undeniable proof that American society is coming apart at the seams. But in the social world inhabited by poor women, a baby born into such conditions represents an opportunity to prove one's worth. The real tragedy, these women insist, is a woman who's missed her chance to have children (p. 6).

Single parenting, especially single motherhood, has been widely discussed in the literature and is a focus of public policy concern. Different causes have been associated with single-parenting, including the increase in female labor force, which decreases the gains of marriage (BECKER et al., 1997), the increase of welfare policies (BECKER et al., 1997; MURRAY, 1994), and the low marriageability of poor, high-schooleducated men, which would decrease single women's motivation to marry, especially among lower educated women (BECKER et al., 1997; CHERLIN, 2009; WILSON, 1990).

Single parenting is often associated with worse outcomes for children (see, for instance, BALDWIN; CAIN, 1980; MCLANAHAN; SANDEFUR, 1997); this is a major reason for the great attention given to this topic. However, other studies have shown that there is no significant difference in the educational achievements of children in two-parent families and those in single-mother families (MORAIS et al., 2010). Additionally, children in families with stepparents perform as well as children in single-parent families ${ }^{1}$ (MCLANAHAN; SANDEFUR, 1997).

There has been much discussion regarding changes in family dimension (e.g.; BUMPASS, 1990; LESTHAEGHE, 1997; STACEY, 1998; FISCHER; HOUT, 2005). One characteristic discussed is the increase of single parenting. Due to this increase, some public policies support marriage among poor women as a solution for overcoming poverty and improving child welfare. Advocating marriage as a solution for improving the conditions of women and children convey the message that marriage is not important for poor women; and because of that, the government needs to create mechanisms to convince them to marry. However, as Promises I can keep shows, poor women see marriage as a luxury; it is something they aspire to, but fear they may never achieve. On the other hand, such women consider bearing children a necessity. They regard it as an absolutely essential part of a young woman's life, and their main source of identity and meaning. Second, single motherhood status does not mean that the child's father is not living in the same household as the mother (at least for part of the child's life). As Bumpass and Riley (1995) have demonstrated, the proportion of

\footnotetext{
* PhD Candidate in Sociology and Demography at University of California, Berkeley and Capes/FULBRIGHT Fellow.

${ }^{1}$ One possible explanation for this is that stepparents do not have the same motivation to invest in their stepchildren as they have to invest in their own biological children (BIBLATZ; RAFTERY, 1999). Another explanation is the fact that stepfamilies are more likely to move and suffer from disruptions in access to community resources (MCLANAHAN; SANDEFUR, 1997).
} 
single-parent families changes significantly depending on whether the analysis includes only those who are formally married or those who cohabitate. They found that unmarried pregnancies that have increasingly resulted in single-parent families account for nearly half of all entries when families are defined by marriage, but for only one third when families are defined by any type of union. The number of single parents appears to have increased using the marital definition, but this number declines substantially when cohabitation is taken into account.

In the first chapter, the authors demonstrate how misleading it is to interpret single parenting as a result of lack of knowledge of contraceptives or of accidental pregnancy. Children are rarely conceived purely by accident. Pregnancy happens due to a desire to create a significant, long-lasting bond through a child, especially within the context of marriage as a dream, or a fragile and rare tie. Other reasons include the desire to escape from a troubled home and the use of a pregnancy in the hope of more intimacy in the relationship. In addition, young women are confident that they can raise a child, thinking that they have already mastered many of its mechanisms because they have spent their childhood embedded in a social network with children. Another very important issue is how they see pregnancy and the meaning of having a baby, a perspective that may differ from that of middle-class women. Children, planned or not, are seen as a gift. Poor women believe that their lives start when they have a baby. This perspective is quite different from middle-class ideas about motherhood, in which women think about living their lives before having a baby. Once poor women become pregnant, the right thing to do is to have the baby, because "the way in which a young woman reacts in the face of a pregnancy is viewed as a mark of her worth as a person" (p. 43).

Another reason why pregnancy comes before marriage is the fact that the news of a pregnancy is a way to test the relationship. An expectant mother may use the pregnancy to test the strength of the bond with her boyfriend and to take a measure of his moral worth. "Women see the perfect boyfriend as a nothing if he does not fulfill his parenting roles" (p. 72) (Chapter 2). Although poor women usually hope that their boyfriends will be with them and report that relationships can be transformed at the magic moment of birth with promises of staying together, most relationships end before the child is in preschool. Among the problems is the man's unwillingness to work even if he can find a job, and the fact that he spends his earnings on partying or unnecessary personal expenses (i.e., computer equipment, clothes, stereo components, and drugs). "Fathers who spend more on themselves than on their kids are not worth much in the mother's eyes" (80) (Chapter 3). Therefore, the main reason these women are not together with their partners is because they consider that the men are not prepared to marry or not worth marrying; it is not because these women do not want to marry.

Similarly, when couples do stay together, they do not necessarily marry. This does not imply a disinterest in marriage by the women. On the contrary, the authors highlight the fact that a retreat from marriage among the young poor flows out of a radical redefinition of what marriage means. Marriage is something special and hard to achieve. It does not mean financial achievements, but a lifelong commitment. Because the poor do not usually believe in divorce, they only marry when they feel secure that the relationship is not threatened by the possibility of it. They also want to be financially independent from their partners - first, as insurance against a marital failure, and second, as a check on the men's power over them (Chapter 4).

Poor young mothers do not view out-ofwedlock birth as a mark of personal failure. Instead, they see it as an act of valor. They also have confidence in their ability to parent their children well. Being a good mother means being there for your child (p 10). In their words, "the true mark of good mothering is the ability to 'hold on,' to continue to support their children in the face of missteps and adversity" (159). As the authors point out, social class plays a significant role in how these mothers measure success. Poor mothers "adopt an approach to childrearing that values survival, not achievement" (166) 
(Chapter 5). As Laureau (2003) points out in her book, middle and poor/working classes have different childrearing rationales. ${ }^{2}$

In sum, why are poor women's standards for prospective fathers so low if their demands for marriageable men are so high? First, because having a child at a young age is a normal and valuable part of life; second, because these women trust their ability to raise a child; and third, because they have high hopes for what the child might do for them. They believe that having a child is a good thing in their lives. They do not think that motherhood has caused hardship but, rather, that it has saved them (Chapter 6). In regards to marriage, poor women see it as something valuable; it is a desirable objective for most of them. They see marriage as a personal achievement that requires a series of steps to be accomplished before they are willing to participate. "(...) [T] here are few differences between the poor and the affluent in attitudes and values toward marriage." Marriage is much less about sex, co-residence, and childrearing than it used to be and, thus, has lost much of its day-to-day significance. At the same time, as the authors highlight, culture could do more to make marriage seem more special, more rarified, and more significant in its meaning (see also CHERLIN, 2009). The most important difference in the way middle class women and poor women view motherhood is that the latter ascribe a higher value to children than the former do. "Though the poor hold a middle-class standard for marriage, they do not, by and large, adopt middle-class childrearing norms. This constitutes the second crucial difference between classes" (210).

The book takes a positive view regarding women perspectives on having children at a young age and before marrying. However, some important issues are left out. First, the long-term consequences of an early pregnancy in women's lives are not discussed. Most of the women interviewed were still young and talked about their lives and perceptions shortly after giving birth. Some studies have shown that young mothers have worse outcomes throughout their lives (e.g.: HORWITZ et al., 1991; OLAUSSON et al., 2001). In contrast, other authors have found that, after controlling for social background and for conditions before the pregnancy, the outcomes are not much different than for women who did not have a baby at a young age (e.g. GERONIMUS; KORENMAN, 1992; STANGE, 2007). This second research finding is closer to the argument in Edin and Kefalas' book. Another important long-term consequence is the intergenerational effects of having a child outside of marriage. Since it is known that family decisions such as marriage, motherhood, and divorce are influenced by parental characteristics and events in parents' lives (e.g.: THORTON Et Al., 2007; WOLFINGER, 2011), an analysis of how this process reproduces a behavioral pattern across generations is important. In the book there is very little discussion and description of the unmarried mothers' parental union histories and marital civil statuses. Finally, it is important to highlight that there is an absence of men's voices; therefore, the incorporation of the fathers' perspective is fundamental for a complete picture of the meaning of marriage and for the process of having a child before a formal union.

The book is an important reading for family researchers, especially during a period in which single parenting has received much attention because of the changes in the sphere of the family and the possible impact single parenting has on children's outcomes and public policy formulation.

\footnotetext{
2 Laureau (2003) concludes that the middle-class has a logic of childrearing called "concerted cultivation," in which parents stress the practice of lots of extra organized activities, language use, and the develop of reasoning. This childrearing logic creates a culture of individualism within the family and emphasizes children's performance.

In poor and working families, the model is called "accomplishment of natural growth," in which parents focus on providing food, safety, and love. There is no emphasis on developing the special talents of their children. Therefore, children in these families have more free time and deeper and richer ties within their extended families.
} 


\section{References}

BECKER, G. S.; LANDES, E. M.; MICHAEL, R. An economic analysis of marital instability. The Journal of Political Economy, v. 85, n. 6, p. 1141-1188, 1977.

BIBLARZ, T. J.; RAFTERY, A. R. Family structure, educational attainment, and socioeconomic success: rethinking the 'Pathology of Matriarchy'. American Journal of Sociology, v. 105, n. 2, p. 321-65, 1999.

BUMPASS, L.L.; RALEY, R. K. Redefining single-parent families: cohabitation and changing family realities. Demography, v. 32, n. 1, p. 97-109, 1995.

GERONIMUS, A.; KORENMAN, S. The socioeconomic consequences of teen childbearing reconsidered. The Quarterly Journal of Economics, v. 107, n. 4, p. 1187-1214, 1992.

HORWITZ, S.; KLERMAN, L.V.; SUNG KUO, H.; JEKEL, J. F. School-age mothers: predictors of long-term educational and economic outcomes. Pediatrics, v. 87, n. 6, p. 862-868, 1991.

LAREAU, A. Unequal childhoods: class, race, and family life. Berkeley: University of California Press, 2003.

LESTHAEGHE, R. Imre Lakatos' views on theory development: applications to the field of fertility theories. IPD-Working Paper 1997-1, VUB, Brussels, 1997.

MCLANAHAN, S.; SANDEFUR, G. Growingup with a single parent: what hurts, what helps. Cambrigde: Harvard University Press, 1997.

MORAIS, T. de A.; GUIMARÃES, R. R. de M.; RIOS-NETO, E. G. O efeito da estrutura familiar sobre a estratificação educacional no Brasil: evidências com base na probabilidade de progressão por série entre 1986 e 2008. Belo Horizonte, UFMG/ Cedeplar, 2010 (Textos para discussão Cedeplar, n. 409). Disponível em: <http:// www.cedeplar.ufmg.br/pesquisas/td/TD\%20 409.pdf>.

MURRAY, C. Losing ground: american social policy, 1950-1980. New York: BasicBooks, 1994.

OLAUSSON, P. O.; HAGLUND, B.; WEITOFT, G. R.; CNATTINGIUS, S. Teenage childbearing and long-term socioeconomic consequences: a case study in Sweden. Family Planning Perspectives, v. 33, n. 2, p. 70-74, 2001.

STANCEY, J. Brave families: stories of domestic upheaval in Late-Twentieth Century America. Berkeley: University of California Press, 1998.

STANGE, K. The causal effect of fertility timing on degree attainment: an identification test using the cumulative nature of schooling. In: PRESENTED AT THE POPULATION ASSOCIATION OF AMERICA, 2007 ANNUAL MEETING. New York, March 29-31, 2007.

THORNTON, A.; AXINN, W. G.; XIE, Y. Marriage and cohabitation. Chicago: University of Chicago Press, 2007.

WILSON, W. J. The truly disadvantage: the inner city, the underclass, and public policy. Chicago: University Of Chicago Press, 1990.

WOLFINGER, N. H. More evidence for trends in the intergenerational transmission of divorce: a completed cohort approach using data from the general social survey. Demography, v. 48, n. 2, p. 581-592, 2001.

Recebido para publicação em 21/11/2011 Aceito para publicação em 05/01/2012 